PROBLEMS

OF EDUCATION

IN THE $21^{\text {st }}$ CENTURY

Volume 58,2014

108

STUDENTS' CONFIDENCE IN THEIR

FINANCIAL MANAGEMENT ABILITIES:

THE ROLE OF SOCIO-DEMOGRAPHIC CHARACTERISTICS AND EDUCATION

\author{
Francka Lovšin Kozina, Nina Ponikvar \\ University of Ljubljana, Slovenia \\ E-mail: francka.lovsin@pef.uni-lj.si, nina.ponikvar@ef.uni-lj.si
}

\begin{abstract}
The aim of this study was to investigate the impact of gender, age, parent's education, scholarship and students' education on students' confidence in their financial management capability and knowledge. In the research, 259 students participated from two different faculties - the Faculty of Education and the Faculty of Economics. This investigation has revealed that the likelihood of students' confidence in their financial management capability and knowledge is significantly smaller for students who do not specialize in economics or business studies, and for female students. The likelihood of confidence in their financial management capability and knowledge also statistically significantly increases with the father's educational level, but, interestingly, not with the mother's. The results also showed, although it is not statistically significant, that students on scholarships on average express a higher confidence in their financial management capability and knowledge. Therefore, the adequacy of the current educational policy (formal and non-formal education) should be considered.
\end{abstract}

Key words: confidence, education, financial literacy, money management, perception.

\title{
Introduction
}

Financial literacy research has grown in recent years as a result of the financial market developments, economic and policy changes on one hand and the economic crisis on the other (Lusardi and Mitchell, 2011). In transitional economies, families face challenges related to lack of experience with different financial services and products such as retail financial services, consumer credits etc., also sometimes due to a bad experience with some financial intermediaries (Kunovskaya, Cude and Koonce, 2013). But, with an inadequate level of financial literacy which results in consumer's high indebtedness, households' bankruptcy etc. was also faced in developed countries such as the USA (Huston, 2010). Lusardy and Mitchell (2011) state also: .. "observed low levels of financial literacy in the U.S. are prevalent elsewhere, rather than specific to any given country of stage of economic development

There are several conceptual definitions of financial literacy. According, to Remund (2010), it can be divided into five categories: (1) knowledge of financial concepts; (2) ability to communicate about financial concepts; (3) aptitude in managing personal finances; (4) skill in making appropriate financial decisions; and (5) confidence in planning effectively for future financial needs. Huston (2010) expands the conceptual definition of financial literacy with an "application dimension": "Financial knowledge is an integral dimension of, but not equivalent to financial literacy. Financial literacy has an additional application dimension which implies that an individual must have the ability and confidence to use his/her financial knowledge to make financial decisions". 
The research focus of this study is students' confidence in their financial literacy. Students are usually not fully financially independent, although they do have money and every day make different decisions related to money. The purpose of this study is to find out how age, gender, education and having regular money (scholarship), impact a student's confidence in their financial management capability and knowledge. The data of $1^{\text {st }}$ grade students are analysed.

\section{Problems of Research}

Several researches in recent years have focused on important factors of financial literacy. Some research findings in developed countries suggest gender differences in terms of financial literacy (Chen and Volpe, 2002; Lusardi and Mitchell, 2008; Zissimopoulos et al., 2008). Davidson, Winland, Anderson and Ward (2012) find that women are "behind in many key areas of financial planning, most notably in money management and investing". They also find that women are better at planning long-term goals but not at basic money management skills and investing. The reason for the lack of women's financial literacy could be because women have less confidence than men due to their traditional role (Sharp, Broomhill, 1988) and because they are more risk-averse than men (Bajtelsmit and Bernasek 1996). Sadker (1999) states that in the socialization process women are not under such pressure to be aggressive and independent as men; they are socialized to be passive which could be connected to a higher risk aversion. The results of Falahati et al. (2011) show that primary socialization agents are the strongest predictor of financial well-being among male students and that female students have a lower level of financial knowledge. On the contrary, Shubert et al. (1999) state that in controlled economic conditions, differences in risky financial choices are not significant. There are not many surveys that focus on women in developing countries. Xu and Zia (2012) find that women have a lower level of financial literacy across almost all countries in both developing and developed worlds. A study by Lusardy and Mitchel (2011) reveals that women (both groups of countries) have a lower level of financial knowledge and also that women know they know less, than do man.

Several studies have shown that parents are important socialization agents in the financial literacy development process (Danes and Dunrud, 1993; Webley and Nyhus, 2006). Shim et al. (2010) studied students' willingness to adopt parental financial role modelling during their first year of college. They found a substantial impact of parents on the financial socialization of students. Those students whose parents were active in teaching them financial topics and showed positive financial behaviour more often regarded their parents as a role model. Students whose parents were a role model also more often reported they had better control over their financial behaviour. The results of this study also show that those parents who had intentionally taught their children about financial management had a greater influence on their children's financial knowledge than school and work experience. Lusardi, Mitchell and Curto (2010) also find that a mother's education is strongly associated with students' financial literacy.

Work experience contributes to students' financial knowledge (Mandell 2008, Mortimer, 2003, Shim et al. 2010). A study by Mortimer (2003) revealed a connection between work experience and a greater sense of responsibility and money management skills. The Mandell (2007) report also shows that those students who work more often save money and are more financially literate. Lusardy and Mitchell (2011) find also, that (both in developed and in developing countries):" Financial literacy is higher among those who are working, and in some countries among the self employed, compared to those who do not work."

Much research in recent years has also focused on the educational impact on financial literacy. Some research shows that financial knowledge is not directly connected with financial behaviour (Mandel and Klein 2009), while Danes (2004) reports positive changes in students' financial behaviour immediately after and three months after completing training. Shim et al. (2010) report that formal financial education during high school years predicts students' financial 
Francka Lovšin Kozina, Nina Ponikvar. Students' Confidence in Their Financial Management Abilities: the Role of Socio-demographic Characteristics and Education

OF EDUCATIC

IN THE $21^{\text {st }}$ CENTURY Volume 58, 2014

110 knowledge, Stone, Wier and Bryant et al. (2008) found that financial learning programmes increase positive financial behaviour and impact on changes in behaviour. Carlin and Robinson (2012) connect financial education with financing choices and consumer behaviour and find that "Students who experienced training were somewhat better at making current-cost/currentbenefit trade-off decisions (spending more today versus spending less today)".

Many researches have addressed the connections between sociodemographic factors, education and financial knowledge, behaviour. But, there remains a need for more in-depth research on students' confidence in their financial management capability and knowledge. According to the Ajzen (1985) theory of planned behaviour, behavioural intentions, which lead to a desired behaviour, depend among others on perceived behavioural control (e.g. knowing that "I am capable of managing my personal finances"). In this investigation, factors which should influence students' confidence in their financial management capability and knowledge were investigated. Research questions were as follows:

1. Do students' involvement in programmes with business/economics subjects play a significant role in students' confidence in their financial management capability and knowledge?

2. Does experience with having a regular income (scholarship) play a significant role in students' confidence in their financial management capability and knowledge?

3. How students' confidence in their financial management capability and knowledge is affected by age, gender and parents education?

\section{Methodology of Research}

A total of 259 students from two different faculties at the University of Ljubljana, i.e. the Faculty of Education and the Faculty of Economics participated in the research. The students were surveyed at the end of their first semester. Randomised sampling of students within groups (at the Faculty of Economics - students with a certain letter stating their surname, at the Faculty of Education first-year students from three different courses) was used.

\section{Sample Characteristics}

The sample thus consists of students from two different study fields with different levels of involvement in financial and economic topics. The students from the Faculty of Economics had attended four different introductory-level courses on business, business law, finance and economics.

Table 1. Sample characteristics according to the students' study fields.

\begin{tabular}{|c|c|c|c|}
\hline Study programmes & Number of economics' courses & $\mathbf{N}$ & $\%$ \\
\hline $\begin{array}{l}\text { FACULTY OF ECONOMICS (FE): } \\
\text { University Degree - Business \& Economics } \\
\text { Sciences (BESc): }\end{array}$ & $\begin{array}{l}4 \\
\text { Microeconomics } 1 \text { Macroeconomics 1, Principles of } \\
\text { Accounting, Introduction to Business, Management }\end{array}$ & 73 & 28.2 \\
\hline Business Administration (BA). & & 72 & 27.8 \\
\hline $\begin{array}{l}\text { FACULTY OF EDUCATION (FED): } \\
\text { Two-subject teacher: Home economics and } \\
\text { biology or chemistry }(\mathrm{He})\end{array}$ & $\begin{array}{l}1 \\
\text { Home Economics (money, budget, market, supply } \\
\text { and demand) }\end{array}$ & 36 & 13.9 \\
\hline Primary education teacher (Pedt) & 0 & 29 & 11.2 \\
\hline Preschool education (Ped) & 0 & 49 & 18.9 \\
\hline
\end{tabular}


Francka Lovšin Kozina, Nina Ponikvar. Students' Confidence in Their Financial Management Abilities: the Role of Socio-demographic Characteristics and Education

PROBLEMS

OF EDUCATION

IN THE $21^{\text {st }}$ CENTURY

Volume 58, 2014

At the Faculty of Education, during their first semester, students of Primary Teacher Education and students of Preschool Education had not attended any economics courses, whereas students of Home Economics had taken part in one course covering economic and financial topics (Table 1).

As evident from Table 2 the majority of the surveyed students were female. At the time of the survey they were on average roughly nineteen and a half years old. $35 \%$ of all students had a regular income (scholarship). The results also show that on average, students of business and economics had a higher average income at their disposal compared to students of educational sciences. On the contrary, a larger share of the latter had been receiving a scholarship at the time of the survey. Interestingly, the share of students with a scholarship was highest among students with preschool education. From Table 2 it can be also seen that students with Business (BESc) and Primary education had on average more educated mothers compared to students from all other fields, whereas no outstanding fact could be observed based on their fathers' educational levels.

Table 2. Sociodemographic characteristics of the sample.

\begin{tabular}{|c|c|c|c|c|c|c|}
\hline \multirow{2}{*}{ Variable } & \multicolumn{6}{|c|}{ Study field (in \%) } \\
\hline & BESc & BA & $\begin{array}{l}\text { Home Eco- } \\
\text { nomics }\end{array}$ & $\begin{array}{l}\text { Primary Edu- } \\
\text { cation Teacher }\end{array}$ & $\begin{array}{l}\text { Preschool } \\
\text { Education }\end{array}$ & $\begin{array}{l}\text { All stu- } \\
\text { dents }\end{array}$ \\
\hline \multicolumn{7}{|l|}{ Gender (\%) } \\
\hline Men & 35.6 & 31.0 & 2.8 & 0 & 0 & 19.0 \\
\hline Women & 64.4 & 69.0 & 97.2 & 100.0 & 100.0 & 81.0 \\
\hline Average Age & 19,44 & 20,25 & 19,31 & 19,25 & 19,00 & 19.45 \\
\hline Average income $(€)$ & 282.7 & 244.2 & 195.5 & 175.3 & 176.7 & 214.7 \\
\hline \multicolumn{7}{|l|}{ Scholarship (\%) } \\
\hline Yes & 30.1 & 23.6 & 33.6 & 34.5 & 63.3 & 35.1 \\
\hline No & 69.9 & 76.4 & 66.4 & 65.5 & 36.7 & 64.9 \\
\hline \multicolumn{7}{|l|}{ Mother's education } \\
\hline Primary school & 6.8 & 16.9 & 2.8 & 7.1 & 10.2 & 9.7 \\
\hline Secondary school & 20.6 & 50.7 & 50.0 & 25.0 & 61.2 & 41.2 \\
\hline $\begin{array}{l}\text { College, professional high } \\
\text { school }\end{array}$ & 24.7 & 26.8 & 30.6 & 32.1 & 20.4 & 26.1 \\
\hline University, MSc, PhD & 47.9 & 5.6 & 16.6 & 35.8 & 8.2 & 23.5 \\
\hline \multicolumn{7}{|l|}{ Father's education } \\
\hline Primary school & 4.2 & 11.8 & 2.8 & \multirow{4}{*}{$\begin{array}{l}10.7 \\
46.5 \\
21.4 \\
21.4\end{array}$} & 10.2 & 7.9 \\
\hline Secondary school & 36.1 & 58.8 & 47.2 & & 55.1 & 48.6 \\
\hline $\begin{array}{l}\text { College, professional high } \\
\text { school }\end{array}$ & 20.8 & 23.5 & $\begin{array}{l}47.2 \\
27.8\end{array}$ & & 22.5 & 22.9 \\
\hline University, MSc, PhD & 38.9 & 5.9 & 22.2 & & 12.2 & 20.6 \\
\hline
\end{tabular}


Francka Lovšin Kozina, Nina Ponikvar. Students' Confidence in Their Financial Management Abilities: the Role of Socio-demographic Characteristics and Education

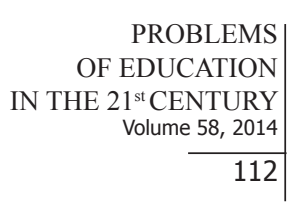

PROBLEMS

$21^{\text {st }}$ CENTURY

Volume 58,2014

112

\section{Data Analysis}

The empirical model was designed to measure the impact of the students' various sociodemographic characteristics (student's gender, age and scholarship, education of their parents) and the education (choice of study) on the students' confidence in their financial management capability and knowledge. An ordered probit regression, which is generally used to estimate the relationships between an ordinal dependent variable and a set of independent variables was applied. An ordinal variable is a variable that is categorical and ordered. With an ordered probit regression, an underlying score is estimated as a linear function of the independent variable and a set of cut points. The ordered outcomes are modelled to arise sequentially as an unobservable latent variable, $y^{*}$, that progressively crosses higher thresholds (Cameron and Trivedi, 2009). In this research $y^{*}$ is the students' unobserved capabilities to manage their finances. But, because it is not possible to observe the $y^{*}$ variable, students' attitudes concerning their capabilities to control and manage their personal finance (Fin_Manag) with four different possible outcomes were observed. The possible answers about the students' confidence in managing their personal finances and about their perception of their knowledge of the topic, i.e. the outcomes, were (1) "not confident, I do not have enough knowledge"; (2) "very limited confidence, my knowledge is poor and I would like to have more knowledge"; (3) "fairly confident, I have relatively good knowledge" and (4) "complete confidence, my knowledge is very good" for managing my finances. The probability of observing outcome $i$ corresponds to the probability that the estimated linear function, plus a random error, is within the range of the cut points estimated for the outcome: , where $u_{j}$ is assumed to be logistically distributed in the ordered probit, $\beta_{1}, \beta_{2}, \ldots, \beta_{k}$ are the regression coefficients, $\kappa 1, \kappa 2, \ldots \kappa_{k-1}$ are cut points with $k$ being the number of possible outcome $\operatorname{Pr}\left(y^{*}=\right.$ outcome $\left._{j}\right)=\operatorname{Pr}\left(\kappa_{i-1}<\beta_{1} x_{1 j}+\beta_{2} x_{2 j}+\ldots+\beta_{k} x_{k j}+u_{j} \leq \kappa_{i}\right)$, is taken as $-\infty$ and $\kappa_{k}$ is taken as $+\infty$. The values of the thresholds $\kappa_{i}$ are estimated as additional parameters of the model. The estimates are obtained by the maximum likelihood (Greene, 2003). The empirical model specification for which the empirical results are presented below in Table 4 is thus:

$$
\operatorname{Pr}\left(y^{*}=\text { outcome }_{j}\right)=\beta_{1} \text { Study_Field }_{j}+\beta_{2} \text { Gender }_{j}+\beta_{3} \text { Age }_{j}+\beta_{4} \text { Father_Ed }_{j}+\beta_{5} \text { Scolarship }_{j}+u_{j}
$$

The impact of the mother's education was also tested. Due to the highly insignificant impact and the length of the table, these estimates are not shown in the table. The results can be, however, obtained from the authors on request. According to Cameron and Trivedi (2009) the sign of the regression parameters $\beta_{i}$, from the specification of the ordered regression model directly carries information about whether the latent variable, $y^{*}$, increases or decreases with the regressor.

\section{Results of Research}

The model examines the interactive roles of the demographic characteristics, education and students' confidence in their financial management capability and knowledge. Table 4 presents the estimates of the various model specifications I-VI based on the ordered probit regression.

The results suggest that the likelihood of students' confidence in their financial management capability and knowledge is significantly smaller for students that did not specialize in economics or business studies, and for female students. It also statistically significantly increases with the father's educational level, but interestingly not with the mother's. Although not statistically significant, we found that students with scholarships on average express a higher confidence in their financial management capability and knowledge (Table 3). 
Table 3. Ordered probit regression model estimates.

\begin{tabular}{|c|c|c|c|c|c|c|c|}
\hline \multirow{2}{*}{\multicolumn{2}{|c|}{$\begin{array}{l}\text { Confidence in students' finan- } \\
\text { cial management capability and } \\
\text { knowledge }\end{array}$}} & I & II & III & IV & V & VI \\
\hline & & \multicolumn{6}{|c|}{ Regression coefficients } \\
\hline $\begin{array}{l}\text { Study Field } \\
0=\text { Economics }\end{array}$ & $\begin{array}{l}0=\text { Economics } \\
1=\text { Education }\end{array}$ & $\begin{array}{l}-0.572 \\
(2.32)^{\star *}\end{array}$ & & & & & \\
\hline \multirow[b]{2}{*}{ Study Field } & \multirow{2}{*}{$\begin{array}{l}0=\text { Economics } \\
1=\text { Teacher of } \\
\text { Home Econom- } \\
\text { ics } \\
2=\text { Preschool } \\
\text { and Primary } \\
\text { school teacher }\end{array}$} & & $\begin{array}{l}-0.2089 \\
(-0.58)\end{array}$ & $-0.0711(0.29)$ & $\begin{array}{l}-0.0414 \\
(-0.11)\end{array}$ & $\begin{array}{l}-0.0233 \\
(-0.06)\end{array}$ & $\begin{array}{l}-0.0337 \\
(-0.09)\end{array}$ \\
\hline & & & $\begin{array}{l}-0.7417 \\
(2.70)^{\star *}\end{array}$ & $\begin{array}{l}-0.5907 \\
(-1.99)^{\star *}\end{array}$ & $\begin{array}{l}-0.5155 \\
(-1.67)^{*}\end{array}$ & $\begin{array}{l}-0.5173 \\
(-1.70)^{*}\end{array}$ & $\begin{array}{l}-0.6120 \\
(1.97)^{\star *}\end{array}$ \\
\hline Gender & $\begin{array}{l}0=\text { male } \\
1=\text { female }\end{array}$ & & & $\begin{array}{l}-0.5461 \\
(-1.72)^{*}\end{array}$ & $\begin{array}{l}-0.5397 \\
(-1.69)\end{array}$ & $\begin{array}{l}-0.6059 \\
(-1.65)^{*}\end{array}$ & $\begin{array}{l}-0.6131 \\
(-1.67)^{\star}\end{array}$ \\
\hline Age & & & & & $\begin{array}{c}0.1053 \\
(1.03)\end{array}$ & & \\
\hline \multirow{3}{*}{ Father's education } & \multirow{3}{*}{$\begin{array}{l}0=\text { primary } \\
1=\text { secondary } \\
2=\text { college, } \\
\text { professional } \\
\text { higher school } \\
3=\text { university, } \\
\text { MSc and PhD }\end{array}$} & & & & & $\begin{array}{l}0.7599 \\
(1.66)^{*}\end{array}$ & $\begin{array}{l}0.8012 \\
(1.80)^{*}\end{array}$ \\
\hline & & & & & & $\begin{array}{l}0.3125 \\
(0.61)\end{array}$ & $\begin{array}{l}0.4296 \\
(0.83)\end{array}$ \\
\hline & & & & & & $\begin{array}{l}0.7602 \\
(1.70)^{*}\end{array}$ & $\begin{array}{l}0.7141 \\
(1.74)^{*}\end{array}$ \\
\hline Scholarship & $\begin{array}{l}0=\text { no } \\
1=\text { yes }\end{array}$ & & & & & & $\begin{array}{l}0.4153 \\
(1.59)\end{array}$ \\
\hline /cut 1 & & -4.2088 & -4.2276 & -4.6195 & -2.6721 & -4.0449 & -3.8483 \\
\hline /cut 2 & & 0.8882 & -0.8919 & -1.2914 & 0.6278 & -0.6836 & -0.4703 \\
\hline /cut 3 & & 1.9409 & 1.9502 & 1.5863 & 3.5248 & 2.2115 & 2.4464 \\
\hline Observations & & 255 & 255 & 254 & 252 & 248 & 248 \\
\hline Pseudo R² & & 0.0106 & 0.0145 & 0.0198 & 0.0211 & 0.0287 & 0.0334 \\
\hline $\operatorname{LR} X^{2}$ & & (1) 5.45 & (2) 7.43 & (3)10.14 & (4)10.68 & (6)14.35 & (7)16.71 \\
\hline Prob $>X^{2}$ & & 0.0195 & 0.0244 & 0.0174 & 0.0204 & 0.0209 & 0.0193 \\
\hline
\end{tabular}

Note: $z$ statistics in parentheses ( ), ${ }^{*} p<0.05, \quad * * p<0.01$.

Table 4 exhibits the average marginal effects $(d x / d y)$ of the considered financial literacy factors. The presented marginal effects are calculated as a change in the probability of a student expressing outcome 4, i.e. complete ability for financial management instead of outcome 3 , i.e. limited ability. These average marginal effects show that the students of education are on average 5.3 percentage points less likely to express the highest possible score of 4 compared to students of economics (Specification I). The lagging behind in terms of financial management skills is on average highest for students with pre-school and primary education (6.1 percentage points in Specification II) who did not have any economic or financial courses in their curriculum. Furthermore, the likelihood of female students reporting full confidence in their financial 
Francka Lovšin Kozina, Nina Ponikvar. Students' Confidence in Their Financial Management Abilities: the Role of Socio-demographic Characteristics and Education

OF EDUCATIOI

IN THE $21^{\text {st }}$ CENTURY Volume 58, 2014

management skills, i.e. a score of 4 , is on average around 5 percentage points lower than for their male colleagues (Specifications III-VI). Not surprisingly and confirming the impact of the family environment, the level of the father's education increases the likelihood of a student's confidence in their own financial management skills. For example, students whose fathers had a postgraduate degree or PhD are on average $6 \%$ more likely to report a score of 4 , namely that they have full confidence in their financial management capability and knowledge.

Table 4. The average marginal effects of the ordered probit regression model.

\begin{tabular}{|c|c|c|c|c|c|c|c|}
\hline \multicolumn{2}{|c|}{$\begin{array}{l}\text { Dependent variable } \\
\text { Confidence in students' financial manage- } \\
\text { ment capability and knowledge }\end{array}$} & I & II & III & IV & V & VI \\
\hline $\begin{array}{l}\text { Study Field } \\
0=\text { Economics }\end{array}$ & $\begin{array}{l}0=\text { Economics } \\
1=\text { Education }\end{array}$ & 0.053 & & & & & \\
\hline \multirow[t]{2}{*}{ Study Field } & \multirow{2}{*}{$\begin{array}{l}0=\text { Economics } 1=\text { Teacher } \\
\text { of Home Economics } \\
2=\text { Preschool and Primary } \\
\text { school teacher }\end{array}$} & & -0.021 & -0.007 & -0.004 & -0.002 & -0.003 \\
\hline & & & -0.061 & -0.049 & -0.043 & -0.042 & -0.049 \\
\hline Gender & $0=$ male and $1=$ female & & & -0.050 & 0.048 & -0.054 & -0.056 \\
\hline Age & & & & & -0.009 & & \\
\hline \multirow{3}{*}{ Father's education } & $0=$ primary; $1=$ =secondary & & & & & 0.057 & 0.061 \\
\hline & $\begin{array}{l}2=\text { college, professional } \\
\text { higher school }\end{array}$ & & & & & 0.019 & 0.025 \\
\hline & $\begin{array}{l}3=\text { university, MSc and } \\
\mathrm{PhD}\end{array}$ & & & & & 0.057 & 0.067 \\
\hline Scholarship? & $\begin{array}{l}0=\text { no } \\
1=\text { yes }\end{array}$ & & & & & & 0.037 \\
\hline
\end{tabular}

\section{Discussion}

Many prior works have documented the importance of education in improving students' financial literacy. Stone, Wiener and Bryant (2008), Rao and Barbera (2005), for example, stated the positive impact of education on financial literacy. Danes (2004), Carlin and Robinson (2012), for example, reported positive changes in students' financial behaviour after completing training. But, there remains a need for more research on students' confidence in their financial knowledge and management capabilities. Students' confidence in their knowledge is very important for a successful transfer of knew knowledge into practice or in other words to successfully complete the financial educational process and achieve the students' financial literacy.

The results of this study added that involvement in programmes with business/economics subjects play a significant role in students' confidence in their financial management capability and knowledge. The results suggest that students' perceptions of their financial management capability (perceived behavioural control) are directly influenced by the education (involvement in programmes with economics' subjects) and also indirectly (their fathers' education).

Lusardi and Mitchel (2011) have noticed gender differences in terms of financial literacy in the international context. In Slovenian research, gender differences were found in students' 
confidence in their financial capability and knowledge. The results of this study coincide with Lusardy and Mitchell (2011) findings, that women are aware of the lack of financial knowledge. The results also suggest that female students could be a vulnerable group of students because of their lower confidence in their financial knowledge and capability.

Experience and responsibility are important in the educational process. In this research, students with scholarships were investigated because a scholarship is a regular, comparable income and students must (usually) return it if they don't fulfil their study requirements. The results of this study have showed that possessing a scholarship is positively (but not statistically significant) connected with a student's confidence.

The results of this study suggest that not all students have equal opportunities to be financially capable. It is possible that a number of students will take on financially inappropriate behaviour from their parents or learn about financial topics according to the principle of learning from their mistakes. The results highlight the importance of planned financial education where, not only the objective facts, but also the confidence and motivation they need to use the new knowledge can be given.

In Slovenia, students can learn about personal financial topics in the fifth grade of primary school (10-11 years old). But in the later years of schooling, only a few students have the opportunity to learn about financial matters. The family's financial socialization can also involve some traps (parents' different behavioural expectations, according to a child's gender, different opportunities for children to independently manage their money, parent's education...). Accordingly, it would make sense to think about a guided financial literacy process at all levels of the education system. Financial topics should be upgraded with students' cognitive development. In this way, the continuity of education until the topic becomes "real" and "useful" could be provided.

Because parents are an important role model - the "first teacher" in the financial literacy process, it would make sense to pay attention to them as well. In a non-formal educational context the motivation of parents to talk with their children about this topic is important. But they should first obtain the necessary knowledge. Already primary school teachers could create educational/motivational websites for parents. It is possible that by educating/motivating parents the likelihood of transmitting wrong financial behaviour could be reduced. They should be encouraged to become actively involved at an early stage of the financial literacy teaching process - helping children with regard to consumer goal setting, saving, playing different educational games (board games, computer simulation games....) with them, and giving them an allowance.... Early parental support is very important for teachers in the formal education system. If parents recognize the importance of this topic for the well-being of their children, they can constructively cooperate in the teaching process (playing a supportive role).

However, on the national level, for those who have completed their formal education and have not studied at business schools, different courses, informational websites, e-lectures and independent advisory centres would be helpful.

\section{Conclusions}

How an individual perceives their knowledge and the skills regarding a particular activity is very important for changing behaviour or realizing behavioural intentions. Confidence in one's knowledge is an important factor of the applied dimensions of financial literacy. The results showed:

- students involvement in study programmes with an economic subject influences the students' confidence in their financial management capabilities and knowledge, those students who specialize in economics or business studies were statistically significantly more confident in their financial management skills and knowledge, 
Francka Lovšin Kozina, Nina Ponikvar. Students' Confidence in Their Financial Management Abilities: the Role of Socio-demographic Characteristics and Education

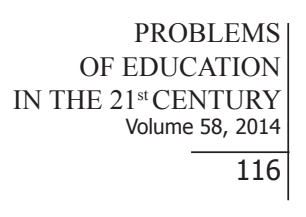

there are gender differences in students' confidence in their financial management capability and knowledge, female students reported statistically less confidence in their financial management skills and knowledge,

- a father's education has a considerable influence on students' confidence in their financial management capability and knowledge,

- although not statistically significant, those students who have scholarships on average express a higher confidence in their financial management capability and knowledge.

The results suggest that introducing financial topics in the school curriculum could be helpful in terms of students' confidence in their knowledge and financial management capabilities. By upgrading knowledge with cognitive development, appropriate (objective) information could be given. In a school environment different appropriate (active) teaching methods provide, not only teaching the financial facts, but also the development of the necessary financial experience for all those who have their own money and those who do not have any yet.

\section{References}

Ajzen, I. (1985). From intentions to actions: A theory of planned behavior. In Kuhl, J. \& Beckman, J. (Eds.). Action-control: From cognition to behavior (pp. 11-39). Heidelberg: Springer.

Bajtelsmit, V. L., \& Bernasek, A. (1996). Why do women invest differently than men? Financial Counseling and Planning, 7 (1), 1-10.

Chen H., \& R. P. Volpe (2002). Gender Differences in Personal Financial Literacy among College Student. Financial Services Review, 11, 283-307.

Carlin, B. I., \& Robinson, T. D. (2012). What Does Financial Literacy Training Teach Us? The Journal of Economic Education, 43 (3), 235-247.

Cameron, A. C., \& Trivedi, P. K. (2009). Microeconometrics using stata. College Station, TX: Stata Press.

Danes, S. M., \& Dunrud, T. (1993). Children and Money: Teaching Children Money Habits for Life. Minnesota Extension Service Publication, HE-FO-6116, University of Minnesota.

Mortimer, J. T. (2003). Working and growing up in America. Cambridge: Harvard University Press

Danes, S. M. (2004). Evaluation of the NEFE High School Financial Planning Program, 2003-2004. Greenwood Villag e, CO: National Endowment for Financial Education. Retrieved from http:// www.hsfpp.org/Portals/0/Documents/NEFE\%20HSFPP\%20Impact\%20Study\%202003-2004. pdf.

Davidson, L., Winland, D. T., Anderson, N. L. \& Ward, G. A. (2012). Gender Gap in Financial Literacy. Financial Finesse Reports - research on financial trends. Executive Summary. Financial Finesse, Inc. Retrieved from http://www.financialfinesse.com/wp- content/uploads/2012/06/2012 Financial_Finesse_Gender_Gap_Research_FINAL.pdf.

Falahati, L., \& Paim, L. H. (2011). A comparative study in money attitude among university Students: A gender view. Journal of American Science, 7 (6), 1144-1148.

How Undergraduate Students Use Credit Cards. Sallie Mae's National Study of Usage Rates and Trends (2009). Retrieved from http://static.mgnetwork.com/rtd/pdfs/20090830_iris.pdf.

Greene, W. H (2003). Econometric Analysis (7th Edition). Prentice Hall.

Hung A. A., Parker, A. M., \& Yoong, J. K. (2009). Defining and Measuring Financial Literacy. Working paper. Department of Labor and the National Institute on Aging via the RAND Royal Center for Financial Decision Making. Retrieved from http://ssrn.com/abstract=1498674.

Huston, S. J. (2010). Measuring financial literacy. The Journal of Consumer Affairs, 44 (2), 296-316.

Kunovskaya, I., Cude, B., Koonce, J. (2013). Money management practices in transition economies: How findings from Financial Literacy Surveys may inform Home Economics educators. IJHE, 6 (1), 48-64.

Lusardi A., \& O. Mitchell (2008). Planning and Financial Literacy: How Do Women Fare? American Economic Review, 98 (2), 413-417.

Lusardi, A., \& Mitchell, S. O. (2009). How Ordinary People Make Complex Economics Decisions: Financial Literacy and Retirement Readiness, mimeo, Dartmouth College. 
Francka Lovšin Kozina, Nina Ponikvar. Students' Confidence in Their Financial Management Abilities: the Role of Socio-demographic Characteristics and Education

Lusardi, A., \& Tufano, P. (2008). Debt Literacy, Financial Experiences, and Overindebtedness, mimeo, Harvard Business School and Dartmouth College.

Lusardi, A., Mitchell, O. S., \& Curto, V. (2010). Financial literacy among the young: evidence and implications for consumer policy. Retrieved from http://www.dartmouth.edu/ alusardi/Papers/ Financial_literacy_young.pdf.

Lusardi, A., \& Mitchell, S. O. (2011). Financial Literacy around the World: an Overwiew. Netspar Discussion Papers No. 2. Retrieved from. http://www.nber.org/papers/w17107

Mandell, L. (2008). Financial Education in High School. In. Annamaria Lusardi (Ed.), Overcoming the Saving Slump: How to Increase the Effectiveness of Financial Education and Saving Programs (257-279). Chicago: University of Chicago Press.

Mandell, L., \& Schmidt Klein, L. (2007). Motivation and financial literacy. Financial Services Review, $16(1), 105-116$.

Mortimer, J. T. (2003). Working and growing up in America. Cambridge: Harvard University Press.

Remund, D. L. (2010). Financial literacy explicated: The case for a clearer definition in an increasingly complex economy. The Journal of Consumer Affairs, 44 (2), 276-295.

Sadker, D. (1999). Gender equity: Still knocking at the classroom door. Educational Leadership, 56 (7), 22-27.

Sharp, R., \& Broomhill, R. (1988). Short changed. Singapore: National Library of Australia.

Shim, S., Xiao, J. J., Barber, B. L., \& Lyons, A. (2009). Pathways to life success: A conceptual model of financial well-being for young adults. Journal of Applied Developmental Psychology, 30 (6), 708-723.

Schubert, R., Brown, M., Gysler, M., \& Brachinger, H. (1999). Financial decision-making: are women really more risk averse? American Economic Review, 89 (2), 381-385.

Webley, P., \& Nyhus, E. K. (2006). Parents' influence on children's future orientation and saving. Journal of Economic Psychology, 27 (1), 140-164.

Webley, P., \& Nyhus, E. K. (2013). Economic socialization, saving and assets in European young adults. Economics of Education Review, 33 (C), 19-30.

Xu, L., \& Zia, B. (2012). Financial literacy around the World: An overview of the evidence with practical suggestions for the way forward. World Bank Policy Research Working Paper No. 6107. Retrieved from: http://papers.ssrn.com/sol3/papers.cfm?abstract_id=2094887.

Zissimopoulos, J. B., Karney, A., \& Rauer, A. (2008). Marital Histories and Economic Well-Being. MRRC Working Paper WP2008-180, 2008.

Advised by Verena Koch, University of Ljubljana, Slovenia

Received: January 23, 2014

Accepted: February 28, 2014

Francka Lovšin Kozina

Nina Ponikvar
PhD., Assistant, University of Ljubljana, Faculty of Education, Kardeljeva av. 16, 1000 Ljubljana, Slovenia.

E-mail: francka.lovsin@pef.uni-lj.si

PhD., Associate Professor, University of Ljubljana, Faculty of Education, Kardeljeva av. 16, 1000 Ljubljana, Slovenia.

E-mail: nina.ponikvar@ef.uni-lj.si
PROBLEMS

OF EDUCATION

IN THE $21^{\text {st }}$ CENTURY

Volume 58, 2014 